\title{
CURRICULAR MATERIAL, CONTENT FAMILIARITY AND TOPIC INTEREST IN INTERACTION: INSIGHTS FROM SPANISH AS A SECOND LANGUAGE PEDAGOGIC MATERIAL
}

\author{
MATERIAL CURRICULAR, FAMILIARIDADE COM O TEMA E INTERESSE PELO TEMA \\ NA INTERAÇÃO: PERSPECTIVA DO MATERIAL PEDAGÓGICO DO ESPANHOL COMO \\ SEGUNDA LÍNGUA
}

\section{Maha Soliman}

\begin{abstract}
In this investigation we report results from a qualitative case study focused on Spanish as a second language teaching context in Chile. With the aim of exploring the relation between curricular material characteristics, topic familiarity and topic interest in reading tasks data has been collected from sixty-four participants using three instruments. The first one is a survey to know more about student's previous experience with reading in their country. The second is a semi structured interview held with professors to gain more clarity about the reading tasks assigned and curricular material used. Lastly, the third, is a focus group where students shared their impressions about the tasks assigned and the material used. Findings support that instructional material complexity reduced topic interest due to the lack of previous knowledge related to the reading material. Students suggested changing all reading tasks to summative evaluation as text complexity frustrated them and they wanted to be rewarded by scores. Those results reveal that curricular design and topic interest could be influenced by the material used according to the topic familiarity of the students.

Keywords: curricular material; content familiarity and topic interest; spanish as a second language teaching.
\end{abstract}

\section{RESUMO}

Nesta investigação reportamos resultados de um estudo de caso qualitativo centrado no contexto do ensino do espanhol como língua estrangeira no Chile. Com o objetivo de explorar a relação entre as características do material curricular, a familiaridade com o tema e o interesse pelo tema na tarefa de leitura, foram recolhidos dados de sessenta e quatro participantes utilizando três instrumentos. O primeiro é um inquérito para saber mais sobre a experiência anterior dos estudantes com a leitura no seu país. $\mathrm{O}$ segundo é uma entrevista semi-estruturada realizada com professores para obter mais clareza sobre as tarefas de leitura atribuídas e o material curricular utilizado. Finalmente, o terceiro é um grupo focal onde os estudantes partilharam as suas impressões sobre as tarefas atribuídas e o material utilizado. As conclusões apoiam que a complexidade do material instrucional reduziu o interesse pelo tema devido à falta de conhecimentos prévios relacionados com o material de leitura. Os estudantes sugeriram a alteração de todas as tarefas de leitura para avaliação sumativa, uma vez que a complexidade do texto os frustrava e queriam ser recompensados com pontuações. Estes resultados revelam que a concepção curricular e o interesse pelo tema poderiam ser influenciados pelo material utilizado de acordo com a familiaridade dos alunos com o tema.

Palavras-chave: material curricular; interesse pelo tema; familiaridade com o tema; ensino do espanhol como língua estrangeira.

\section{INTRODUCTION}

Topic familiarity and topic interest are two key elements in educational settings where reading is considered as a main activity. The first one refers to having previous knowledge related to the reading topic that facilitates its interpretation. While the second one is associated with the intrinsic interest of the learner that motivates him/her to continue reading the text and make the effort to understand it (SHAKOURZADEH and IZADPANAH, 2020). Topic interest is relevant as it enhances text comprehension in the sense that interested students are able to dedicate themselves to reading and focus on the task they handle (SCHIEFELE, 1999). Also, readers familiar with topics have enough previous knowledge to apply this information to new contexts and learn from texts (MCNAMARA and KINTSCH, 1996).

In this context, investigations in first language discuss the role of topic familiarity in students' decisions while selecting a text for reading and evaluating the relevance of arguments for the task achievement and completion (BRÅTEN; MCCRUDDEN; STANG LUND; BRANTE and STRØMS $\varnothing$, 2018). In L2 teaching setting, the study of topic familiarity and topic interest has been usually linked to other variables.

\footnotetext{
* Pontificia Universidad Católica de Valparaíso (PUCV), Valparaíso, Chile. maha.soliman@pucv.cl

Orcid: https://orcid.org/0000-0001-5751-8810
} 
In EFL teaching setting Mahmoudi and Mahmoudi (2017) proved that language proficiency override topic familiarity in reading comprehension. On the other hand, Erçetin (2010) studied the interaction between prior knowledge and topic interest and her results indicate that both variables are correlated because student with low interest in topic and less world knowledge used more annotation while reading in L2. In this regard, Martínez (2009) reported significant effect of topic familiarity on intermediate EFL learners' text comprehension.

Those studies face the challenge that topic familiarity and topic interest are inseparable from other variables. For this reason, a qualitative study is needed to show a different perspective on this issue. Also, studies are mainly focused in EFL context while other languages such as Spanish are receiving much less attention and more findings are needed to confirm or maybe disconfirm the interaction of topic familiarity and topic interest with other variables in Spanish L2 reading. Two empirical studies carried out by Pulido $(2004 ; 2007)$ support the argument that topic familiarity increases incidental lexical acquisition and inferencing, but descriptive studies are needed to clarify the relation between curricular material characteristics, topic familiarity and topic interest in Spanish language. For this reason, the aim of this investigation is to explore the relation between curricular material, topic familiarity and topic interest in Spanish L2 teaching context.

\section{THEORETICAL FRAMEWORK}

The curricular design is becoming a key element in structuring teaching programs and fostering effective learning techniques. The curriculum determines the course of the systematically organized teaching-learning process and it is shaped according to the professional that program aims to train and the skills to be developed. Similarly, curricular design in second languages involves describing teaching material used, and course design involved to facilitate the mastery of the target language.

Accordingly, content-based approaches with focus on the instructional material visualize curriculum as a main tool for knowledge construction in language teaching (MORTON, 2019). Meanwhile, multiliteracies approach study curricular considerations conceived as situated and transformed practice that aims at constructing meaning based on linguistic and multimodal resources (MENKE and PAESANI, 2019). In this practice, students prefer reading material related to their areas of study or their personal interest (STOLLER, 2004; MCKENNA and ROBINSON, 2006; AKBARI and RAZAVI, 2016; ALTALIB, 2019).

Regarding the course design Moreno and Malovrh (2020) tested the effect of a flipped-blended course on the improvement of the four language skills in beginner Spanish learners and compared it with face-to-face classroom instruction. Their findings show a major improvement in the four skills using flipped classroom pedagogical approach. In this respect, Gironzetti, Lacorte, Merediz and Bartis (2020) redesigned a second language course according to the students' needs and in coherence with the contribution of each of the contents to the four linguistic skills. Overall, their findings offered empirical support to the argument that a solid curriculum should be designed based on students' learning goals and should tap into their skills and background knowledge to achieve nuanced performance in second language (PAESANI, 2017).

This means that students are considered as active social agents who are responsible for their learning process. According to Stoller students should participate in reading task design as (2015, p. 154), "when given choices, students are likely to take the task more seriously and enjoy being a reader". At the same time, Iranian EFL students were willing to select learning materials based on their own topic familiarity and topic interest (SHAKOURZADEH and IZADPANAH, 2020). Perhaps because of this, interesting learning materials increased incidentally EFL student's vocabulary knowledge (AKBULUT, 2020). While text difficulty increases mind wandering and reduces interest in the learning topic (SOEMER and SCHIEFELE, 2019).

For this reason, it seems that material selection could change the whole course design and technology used. Especially in context in which content is usually separated from language teaching as if they were different skills. This separation reflects a need for more research about the challenges of curriculum implementation in discipline-specific courses in second language teaching and in this respect the present study intends to contribute by reporting data from a Spanish teaching setting in Chile. 


\section{METHODOLOGY}

\subsection{Design and type of study}

This study adopted a qualitative exploratory case study (MERRIAM and GRENIER, 2019). In general terms, qualitative research reveals the way multiple factors interact in a specific context and the reason why. Its richness lies in addressing various factors of the reality under study not in an experimental context, but in a natural one; this allows for an in-depth interpretation of its intrinsic aspects (CRESWELL, 2013).

\subsection{Instruments}

To portray the experience of the students with the reading material in their country and in Chile, three instruments have been elaborated and validated by 12 experts in Spanish and English L2 teaching. The first one is a student survey, the second one is a semi-structured interview and finally, the third one is a focus group with both students and professors (Appendix A, B and C). The three of them intend to shed light on the contrast of exposure to reading material in the two different academic contexts and its implications.

\subsection{Participants}

This investigation has been held during the first semester of the 2019 academic year and counted with the participation of sixty US university students (ages ranged from 19 to 21 years) and four Chilean professors (30-40 years). All students started learning Spanish from school and attended Spanish undergraduate courses at their country of origin. Data collection took place in a Spanish as a second language Exchange program in Chile, specifically in Literature and History courses. All of them participated by signing an informed consent form and students had to prove their level of language proficiency by presenting a certificate or taking a diagnostic test. The level required was B2-C1 to avoid any linguistic issues that might affect student's reading comprehension.

\subsection{Procedure}

To gain information about students' previous knowledge a survey has been sent to them. Subsequently, two semistructured interview have been held with each one of the academics to know more about the material used for the class and the reading task they assign. Finally, eight focus group sessions have focused on the topic interest of the students and how they perceive the reading material. All sessions have been audio recorded for transcription and later analysis.

All data have been added to Nvivo 12 and a content analysis has been held by the investigator. Analysis led to general and specific categories that represent the case study. Then, a second coder has been asked to make the same coding process again to make sure results are objective (QSR, 2018). The intercoder reliability has been calculated directly by the Nvivo program and it achieved $98.30 \%$ as the second coder suggested precising the label of some categories to be more representative and explicative. Also, to add some descriptive richness by addressing all the details and dimensions of the case studied.

\section{RESULTS AND DISCUSSION}

Findings have been organized in three major themes in coherence with the focus of this investigation. The first theme is the topic familiarity, the second one is the curricular material characteristics and finally the third one is related to topic interest.

\subsection{First theme: Topic familiarity of Spanish learner}

In order to determine the topic familiarity of the students a main research question had to be answered regarding to what extent their previous knowledge is related to the curricular content studied in Chile. For this reason, a comparison had to be made between their previous knowledge and their actual one to determine whether 
their experience is enough to build upon and understand textbooks during reading or not. Consequently, this theme unfolds in two sub-themes that address experience with reading in the second language in learner's country of origin and in the country of the exchange program as resumed in Table 1.

For this purpose, to know more about learner experience with reading in his/her country three main instruments were used to gather information about the learners' previous and current experience with learning and reading in Spanish. Students' prior experience with learning and reading was determined through the student survey and focus groups. In contrast, their experience during the exchange program was addressed by the semi-structured interview with the professors.

Table 1. Summary of the first theme.

\begin{tabular}{|c|c|c|c|c|}
\hline \multicolumn{5}{|l|}{ Topic familiarity } \\
\hline $\begin{array}{l}\text { Research } \\
\text { question: }\end{array}$ & \multicolumn{4}{|c|}{$\begin{array}{l}\text { To what extent Spanish learner's prior knowledge is associated with the disciplinary content of the } \\
\text { textbooks studied during the exchange program? }\end{array}$} \\
\hline Instruments used: & \multicolumn{4}{|c|}{$\begin{array}{l}\text { Survey } \\
\text { Focus group } \\
\text { Semi-structured interview }\end{array}$} \\
\hline $\begin{array}{l}\text { Theme 1: Topic } \\
\text { familiarity }\end{array}$ & \multicolumn{4}{|c|}{$\begin{array}{l}\text { Personal experiences with reading before and during joining the Exchange Program. This theme is } \\
\text { explained through two sub-themes: } \\
\text { 1. Readers' experiences in the home country } \\
\text { 2. Experiences in the exchange program }\end{array}$} \\
\hline Sub-theme & Factor & \begin{tabular}{|c|} 
Definition \\
\end{tabular} & Example & Frequency \\
\hline \multirow{3}{*}{$\begin{array}{l}\text { 1. Readers' } \\
\text { experiences in the } \\
\text { home country } \\
\text { First contact of } \\
\text { the learner with } \\
\text { reading tasks }\end{array}$} & $\begin{array}{l}\text { Experience with reading } \\
\text { in general Spanish } \\
\text { courses }\end{array}$ & $\begin{array}{l}\text { Experiences with courses } \\
\text { focusing on the development } \\
\text { of the four language skills } \\
\text { without necessarily focusing } \\
\text { on any specific disciplinary } \\
\text { content. }\end{array}$ & $\begin{array}{l}\text { "Some students do not } \\
\text { have a direct connection to } \\
\text { political science. They study } \\
\text { general Spanish courses or } \\
\text { Literature. Even if they had } \\
\text { studied Spanish Literature, } \\
\text { they have not studied Chilean } \\
\text { Literature" (I2. History 2.19, } \\
\text { Professor). }\end{array}$ & 36 \\
\hline & $\begin{array}{l}\text { Familiarity with reading } \\
\text { tasks }\end{array}$ & $\begin{array}{l}\text { Second language learning } \\
\text { experiences where the reader } \\
\text { has been exposed to reading } \\
\text { tasks before joining the } \\
\text { exchange program. }\end{array}$ & $\begin{array}{l}\text { Percentages from the student } \\
\text { survey (Graphic 2) }\end{array}$ & 49 \\
\hline & $\begin{array}{l}\text { Positive experiences with } \\
\text { reading tasks }\end{array}$ & $\begin{array}{l}\text { Second language learning } \\
\text { experiences where students } \\
\text { have had a good experience } \\
\text { with reading tasks before } \\
\text { coming to Chile. }\end{array}$ & $\begin{array}{l}\text { Percentages from the student } \\
\text { survey (Graphic } 3 \text { ) }\end{array}$ & 46 \\
\hline $\begin{array}{l}\text { 2. Experience } \\
\text { in the exchange } \\
\text { program }\end{array}$ & $\begin{array}{l}\text { Negative experiences } \\
\text { with assigned texts }\end{array}$ & $\begin{array}{l}\text { Experiences of second } \\
\text { language learning in which } \\
\text { learners report difficulties } \\
\text { with text comprehension. }\end{array}$ & $\begin{array}{l}\text { Percentages from the student } \\
\text { survey (Graphic } 4 \text { ) }\end{array}$ & 51 \\
\hline $\begin{array}{l}\text { Experience } \\
\text { with reading } \\
\text { assignments in the } \\
\text { new context of } \\
\text { student mobility } \\
\text { in Chile. }\end{array}$ & $\begin{array}{l}\text { Reader preference for } \\
\text { tasks with summative } \\
\text { assessment }\end{array}$ & $\begin{array}{l}\text { Second language learning } \\
\text { experiences in which the } \\
\text { reading task is preferred to } \\
\text { be summative }\end{array}$ & $\begin{array}{l}\text { "These steps are time } \\
\text { consuming and require a lot } \\
\text { of analysis. I think if there is } \\
\text { a score it is better, because } \\
\text { then I can feel that it makes } \\
\text { sense to work so hard" (FG2. } \\
\text { History 2.76, Student3). }\end{array}$ & 12 \\
\hline
\end{tabular}

Source: Elaborated by the author of this article 
The sub-theme of experience with reading in the country of origin was shaped by three factors that impacted previous experience. The first factor highlighted that the students' experience of the courses revolved around the development of the four language skills without necessarily focusing on any specialized disciplinary content, as one of the professors makes clear:

"Before, students from Spanish majors were joining these courses. So, it was for people who studied Spanish and literature classes and today the student of these courses may have studied a couple of classes specialized in something else. I don't know, it's very different from what it was at the beginning" (I2. Literature 2. 30, Professor).

Also, according to the results of the student survey to which the 60 learners responded, the Spanish courses to which the students were exposed in their home country were general. These courses focused on grammar (43\%), conversation (21\%), Spanish culture (18\%), and phonetics (12\%). As can be seen in Graphic 1, only six percent of the students had experience with specific Spanish courses.

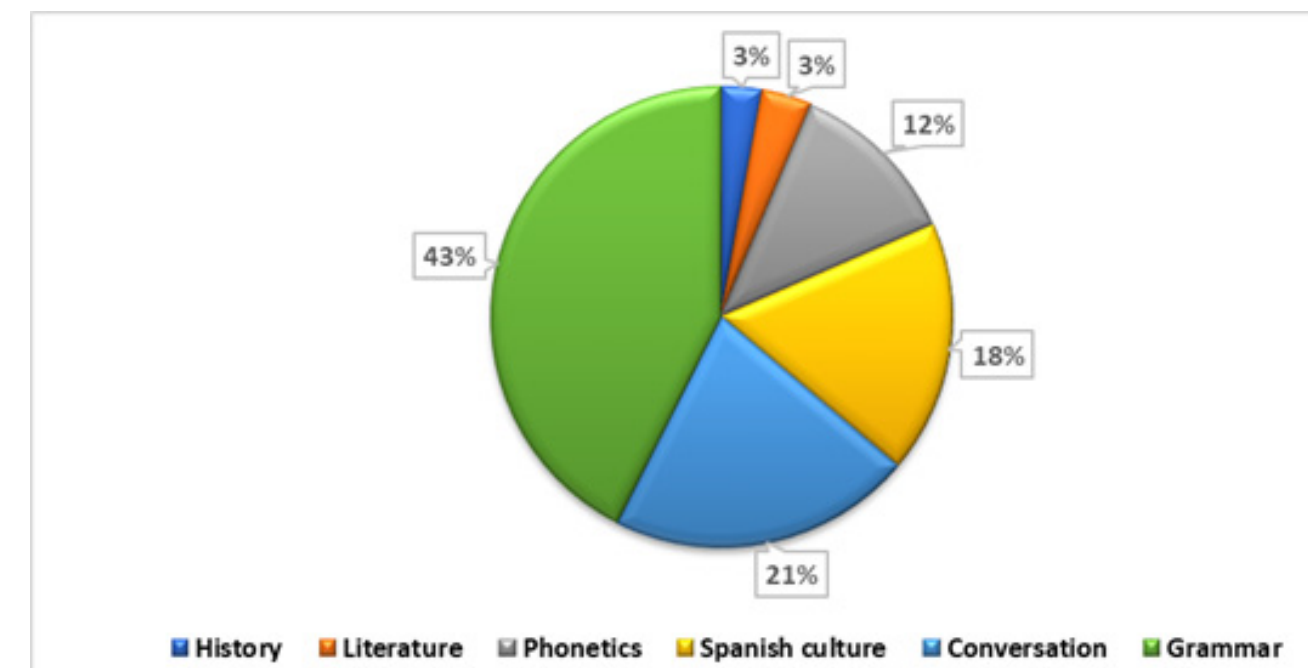

Graphic 1. Experience with Spanish courses before joining the exchange program

The second factor refers to learners' familiarity with reading tasks. This is fulfilled as the learner reports having been exposed to reading tasks during their second language learning process in their home country, before joining the exchange program. $83 \%$ of the learners had previous experience with reading in their home country, as can be seen in Graphic 2.

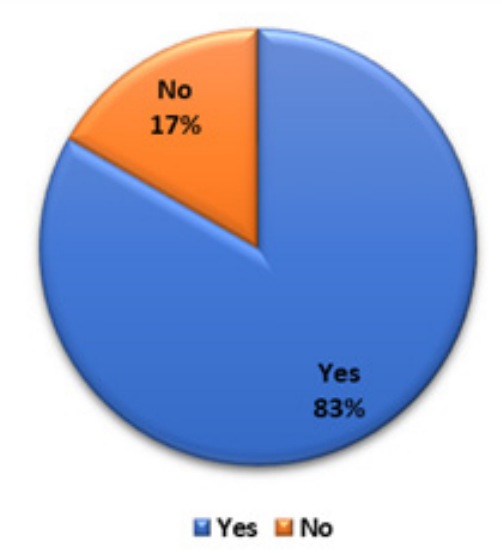

Graphic 2. Previous experience with reading tasks at home country

The third factor ranks this experience with reading assignments before coming to Chile as positive, as confirmed by $92 \%$ of the students in the survey (Graphic 3 ). This positive experience with reading was probably due to the general nature of the courses they had before enrolling in the Chilean ones. 


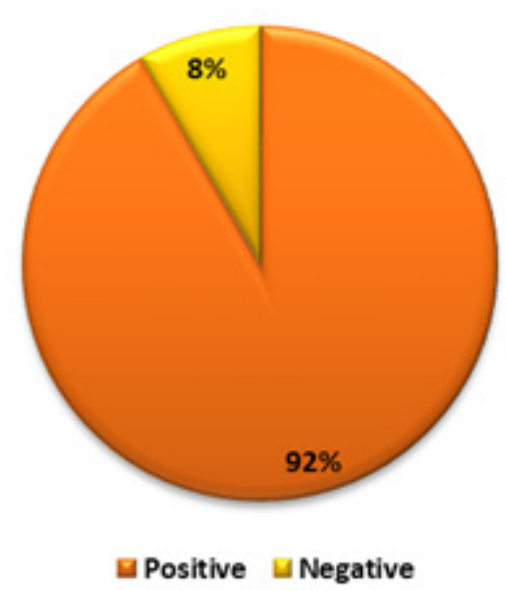

Graphic 3. Students' evaluation of the experience with reading tasks.

On the other hand, the second sub-theme contrasts this previous experience with reading in the home country with the experience during the exchange program. Two factors explain the experience with reading tasks in the new context of student mobility in Chile. The first characterizes this experience as negative, given that students had difficulties with texts.

As a consequence of the generality of texts and courses in the home country, $90 \%$ of students reported having experienced difficulties in handling texts during the exchange in Chile, as mentioned in Graphic 4.

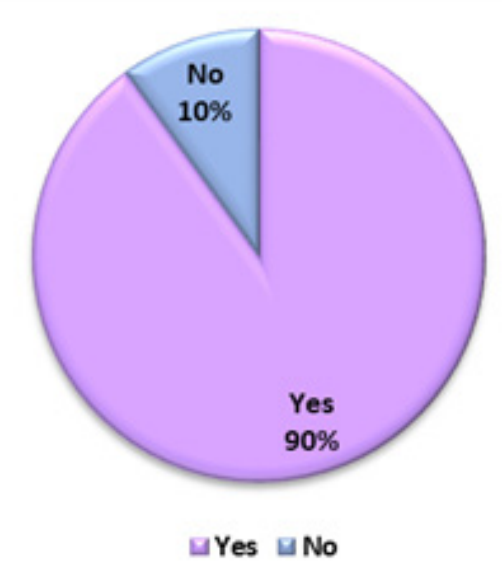

Graphic 4. Difficulties with texts during the exchange.

For this particular reason students mentioned in the focus groups that they prefer summative evaluations for reading tasks in Chile as they require a lot of effort to prepare them. Perhaps the differences of text complexity and task requirements in Chile and US were the reasons as confirmed by one of the students during the focus group.

"Well, I think all reading tasks here should be rewarded with scores. You have any idea how much time I need to translate all the text, understand it, analysis it and then prepare a presentation. I really think that reading tasks in US were quite easy and general. Here texts include too many technical words and are more specific than there" (FG1. Literature 1.6, Student9).

\subsection{Second theme: curricular material characteristics}

The results of the analysis indicated that this theme is associated with comprehension problems, which are attributed to the inherent characteristics of the curricula used in the Spanish literacy framework. Findings have been organized in three sub emerging themes that detail these problems, as shown in Table 2. 
Table 2. Summary of the second theme

\begin{tabular}{|c|c|c|c|c|}
\hline \multicolumn{5}{|c|}{ Curricular material characteristics } \\
\hline Research question: & \multicolumn{4}{|c|}{ What curricula characteristics impact topic interest? } \\
\hline Instruments used: & \multicolumn{4}{|c|}{$\begin{array}{l}\text { Focus group } \\
\text { Semiestructured interview }\end{array}$} \\
\hline $\begin{array}{l}\text { Theme 2: Problems } \\
\text { of comprehension } \\
\text { attributed to curricular } \\
\text { material characteristics }\end{array}$ & \multicolumn{4}{|c|}{$\begin{array}{l}\text { Features of the curricula that make it difficult to understand. This theme is described through three } \\
\text { sub-themes: } \\
\text { 1. Linguistic characteristics of curricular texts. } \\
\text { 2. Characteristics of the selected text type } \\
\text { 3. Thematic characteristics of text }\end{array}$} \\
\hline Subtheme & Factor & Definition & Example & Frecuency \\
\hline $\begin{array}{l}\text { 1. Linguistic } \\
\text { characteristics }\end{array}$ & $\begin{array}{l}\text { Lexical } \\
\text { characteristics }\end{array}$ & $\begin{array}{l}\text { Difficulties with } \\
\text { comprehension caused by the } \\
\text { vocabulary used in the text. }\end{array}$ & $\begin{array}{l}\text { "Obviously now via e-mail, it's } \\
\text { simpler, they write to me and tell } \\
\text { me that they didn't understand } \\
\text { these ten words because they } \\
\text { are Chileanisms" (I2. Literature } \\
2.49 \text {, Professor). }\end{array}$ & 44 \\
\hline \multirow{4}{*}{$\begin{array}{l}\text { 2. Characteristics of the } \\
\text { selected text type } \\
\text { Inherent characteristics } \\
\text { related to the type } \\
\text { of text used in the } \\
\text { exchange program } \\
\text { (narrative/expository). }\end{array}$} & $\begin{array}{l}\text { Narrative texts } \\
\text { open ending }\end{array}$ & $\begin{array}{l}\text { Difficulties with } \\
\text { comprehension of narrative } \\
\text { texts associated with } \\
\text { contemplating an open } \\
\text { ending and/or more than one } \\
\text { possible interpretation of the } \\
\text { protagonists' actions. }\end{array}$ & $\begin{array}{l}\text { "The short story doesn't tell } \\
\text { what happened at the end, but } \\
\text { I think it's interesting that the } \\
\text { author doesn't mention it" (P5. } \\
\text { Literature 2, professor). }\end{array}$ & 20 \\
\hline & $\begin{array}{l}\text { Narrative texts } \\
\text { /Indirect Message }\end{array}$ & $\begin{array}{l}\text { Difficulties with } \\
\text { comprehension of narrative } \\
\text { texts that occur when } \\
\text { language is no longer literal } \\
\text { but relies on figurative } \\
\text { meaning. }\end{array}$ & $\begin{array}{l}\text { "They have a lot of hidden } \\
\text { messages and I need to work } \\
\text { more on determining the } \\
\text { meaning of the words because } \\
\text { it is not necessarily the literal } \\
\text { meaning" (FG2, Literature 1.41, } \\
\text { Student 9.2). }\end{array}$ & 19 \\
\hline & $\begin{array}{l}\text { Narrative } \\
\text { texts/Lack of } \\
\text { contextualization }\end{array}$ & $\begin{array}{l}\text { Difficulties with the } \\
\text { comprehension of literary } \\
\text { texts that occur when the } \\
\text { text does not contextualize } \\
\text { the historical moment it } \\
\text { represents. }\end{array}$ & $\begin{array}{l}\text { "if you are not from a nearby } \\
\text { country, you don't know this and } \\
\text { you read a story that is talking } \\
\text { about this event directly or } \\
\text { indirectly it will be very difficult } \\
\text { to understand because you don't } \\
\text { understand the context and } \\
\text { therefore you won't understand } \\
\text { the message, you will only } \\
\text { understand the words, but not } \\
\text { what they are trying to say" } \\
\text { (FG2. Literature 2.44, Student } \\
\text { 3.2). }\end{array}$ & 8 \\
\hline & $\begin{array}{l}\text { Expository } \\
\text { texts/Lack of } \\
\text { contextualization }\end{array}$ & $\begin{array}{l}\text { Difficulties with the } \\
\text { comprehension of expository } \\
\text { texts that occur when the } \\
\text { text does not contextualize } \\
\text { the historical moment it } \\
\text { represents. }\end{array}$ & $\begin{array}{l}\text { "Political, historical, cultural } \\
\text { circumstances may cause some } \\
\text { difficulty in understanding } \\
\text { the text" (FG2. History 2.10, } \\
\text { Student 6). }\end{array}$ & 5 \\
\hline
\end{tabular}




\begin{tabular}{|c|c|c|c|c|}
\hline \multirow{2}{*}{$\begin{array}{l}3 \text { Thematic } \\
\text { characteristics of text } \\
\text { Characteristics of the } \\
\text { topics addressed in the } \\
\text { didactic resources }\end{array}$} & Authentic texts & $\begin{array}{l}\text { Difficulties that arise when } \\
\text { authentic texts are not } \\
\text { adapted to the learners' level } \\
\text { but are presented in their } \\
\text { original form without any } \\
\text { adaptation. }\end{array}$ & $\begin{array}{l}\text { "I had never thought about } \\
\text { choosing texts that are aimed at } \\
\text { students of Spanish L2, because } \\
\text { I always want to continue with } \\
\text { this idea that this class is of an } \\
\text { advanced level that they can read } \\
\text { the same as any native speaker } \\
\text { of the language" (I2. Literature } \\
2.85 \text {, Professor). }\end{array}$ & 22 \\
\hline & $\begin{array}{l}\text { Texts with } \\
\text { emphasis on Latin } \\
\text { American cultural } \\
\text { and historical } \\
\text { context }\end{array}$ & $\begin{array}{l}\text { Comprehension difficulties } \\
\text { due to the specialization } \\
\text { of the text in the Latin } \\
\text { American socio-cultural } \\
\text { context. }\end{array}$ & $\begin{array}{l}\text { "I think it's because all we had } \\
\text { read before coming here were } \\
\text { texts on Spanish literature or US } \\
\text { history, but we had never read } \\
\text { anything related to Chile or any } \\
\text { Latin American country" (FG2. } \\
\text { Literature 1.87, Student 3.2). }\end{array}$ & 11 \\
\hline
\end{tabular}

Source: Elaborated by the author of this article

The first sub-theme was linked to the linguistic features of the text, mainly the vocabulary involved. That is to say, those difficulties that learners faced when the vocabulary was infrequent or belonged to a variation of the second language that they were not familiar with. For example, the texts contained Chileanisms with which the language learner was unfamiliar, as the professor in charge of one of the Literature courses stated:

"The experience has shown me that at least in terms of the text and the stories, they do understand them, and sometimes it is more difficult for them than others. Especially if they include, for example, more Chilean expressions" (I2. Literature 2. 87, Profesor).

The second sub-theme addressed the lack of historical contextualization of expository and narrative texts as explained by a student in a focus group in a literature course:

"if you are not from a nearby country, you don't know this and you read a story that is talking about this event directly or indirectly it will be very difficult to understand because you don't understand the context and therefore you won't understand the message, you will only understand the words, but not what they are trying to say" (FG2. Literature 1.44, Student 3.2).

For this reason, if the reader did not have prior knowledge associated with the socio-historical context of the text, it was difficult to interpret it. On the other hand, three factors have been recognized as other related difficulties in narrative texts.

The first of these factors is due to the open ending of the narrative text may make them contemplate more than one possible interpretation of the actions of the protagonists. This makes it difficult to determine with certainty what was happening in the text, as the interpretation becomes subjective and the reader does not get to know if what he/she understood or the conclusion he/she reached was correct or not, as one of the students explained:

\footnotetext{
"How do you think the father died?" (P5. Literature 2.3, Professor)

"I'm not sure" (P5. Literature 2.3, Student 12)

"Nobody can be sure, the story doesn't say at the end how he died" (P5. Literature 2.3, Professor).
}

The second factor related to the difficulty of narrative texts centered on the indirect message that influenced the comprehension of narrative texts. This influence was observed in the non-literal language and in the figurative meaning, which together made the interpretation of the texts difficult. In addition, to the fact that these texts were discipline-specific, as stated by one of the participants in a focus group in one of the literature courses:

"For me, the specific discipline course material is what makes it more difficult to read. It is not the same to read a text specialized in economics as a general news article or to read a literary text with a metaphorical or poetic meaning" (FG2. Literature 2.12, Student $5.1)$. 
In this case, knowing the key vocabulary of the reading did not help the students to understand it and, therefore, they felt frustrated for having invested time in translating the unknown words in the text, without achieving the expected outcome as one student explained in one of the focus groups:

"Texts are content-specific and that is why it is difficult to understand them because if you try to translate a short story you usually don't understand it well. They have several references, set phrases, metaphors, morals; no matter how hard I work, it is not easy to understand everything" (FG2. Literature 2.20, Student 3.2).

The third sub-theme explored the thematic characteristics of the texts taught in this Spanish literacy context. In general terms, these were the characteristics of the didactic resources used in the teaching context, regardless of whether they were narrative or expository. Firstly, the texts were characterized by being authentic or not adapted to the learners' level of proficiency. Presenting the texts in their original version to second language learners made it hard to reduce their complexity.

"Short stories are extracted from anthology books that are for Chileans" (I2. Literature 2.51, Professor).

"I had never thought when I was choosing texts that it's for Spanish L2 students because I always want to continue with this belief that this class is for advanced level and that they can read the same as any native speaker of the language" (I2. Literature 2.85, Professor).

In this context, some studies present arguments in favor of the use of authentic text in the second language classroom, as it introduces the student to the target language and favors the student's cultural and linguistic immersion (GARCÍA, 2007; GILMORE, 2011; GUO, 2012; HANSEJORDET, 2012; SEQUERO, 2015; AKBARI and RAZAVI, 2016). Other studies declare their opposition to the use of authentic material because its difficulty at the linguistic level works against its purpose as a comprehensible teaching resource (ANDRIJEVIĆ, 2010; SALAS, 2013; ZYZIK and POLIO, 2017).

Finally, the texts were distinguished by their specialization in the Latin American socio-cultural context, which was unfamiliar to the exchange students, and for this reason, they did not manage to link it to their previous experience.

"I think it is because all we had read before coming here were texts on Spanish Literature or US History, but we had never seen anything related to Chile or any Latin American country" (FG2. Literature 1.87, Alumna3.2).

\subsection{Third theme: Topic interest of Spanish learner}

This theme outlines the impact of the curricular design on the topic interest as seen in Table 3 . This theme has been divided into three main sub-themes: the first studied the negative impact on the learners' participation in the reading activities; the second dealt with the consequences of the curricular complexity which highlight the learners' lack of prior knowledge about reading content; and the third participants' lack of experience in other exchange contexts that could have prepared him/her for the reading material in Chile.

The first sub-theme covered three factors that showed to what extent text difficulty affected the interaction in class based on the reading material. The first of these factors addressed shyness as a personality trait that made it difficult for students to participate in group activities to communicate what they had read. This was pointed out by one of the History professors in the semi-structured interview:

"I have the impression especially after the first two presentations that those who present tend to get very nervous" (I2. History 2.85, Professor). 
Table 3. Summary of the third theme

\begin{tabular}{|c|c|c|c|c|}
\hline \multicolumn{5}{|l|}{ Topic interest } \\
\hline Research question: & \multicolumn{4}{|c|}{ To what extent does text complexity affect interaction in the classroom? } \\
\hline Instruments used: & \multicolumn{4}{|c|}{$\begin{array}{l}\text { Survey } \\
\text { Focus group } \\
\text { Semiestructured interview }\end{array}$} \\
\hline $\begin{array}{l}\text { Theme 2: Negative } \\
\text { impact of curricular } \\
\text { complexity on the } \\
\text { learner's interest }\end{array}$ & \multicolumn{4}{|c|}{$\begin{array}{l}\text { Difficulties in understanding the texts assigned for the reading task that impacts the subsequent } \\
\text { participation in class. This theme is explained through three sub-themes: } \\
\text { Personality traits } \\
\text { Lack of prior knowledge } \\
\text { Lack of experience in other exchange contexts. }\end{array}$} \\
\hline Subtheme & Factor & Definition & Example & Frecuency \\
\hline \multirow[t]{3}{*}{$\begin{array}{l}\text { 1. Personality traits } \\
\text { that reflects the } \\
\text { negative effect of text } \\
\text { complexity }\end{array}$} & Shyness & $\begin{array}{l}\text { Personality trait that makes } \\
\text { it difficult for the student to } \\
\text { participate in group activities } \\
\text { to communicate what he/she } \\
\text { has read. }\end{array}$ & $\begin{array}{l}\text { "I mentioned that this class takes } \\
\text { an hour and a half. And they tell } \\
\text { me, professor, how are we going } \\
\text { to talk for an hour and a half, and } \\
\text { I make the joke, well, don't talk } \\
\text { for an hour and a half, talk for an } \\
\text { hour and } 26 \text { minutes. Usually, they } \\
\text { end up talking around } 45 \text { minutes } \\
\text { and that's why there's this idea } \\
\text { of audience participation. And } \\
\text { sometimes when I see that things } \\
\text { are a bit off, I try to support them } \\
\text { a bit. I don't leave them drifting } \\
\text { and they know that. (I2. Literature } \\
2.36 \text {, Professor) }\end{array}$ & 5 \\
\hline & Individualism & $\begin{array}{l}\text { Preference of independency } \\
\text { and individual task assignment }\end{array}$ & $\begin{array}{l}\text { "I tried to group them in pairs or } \\
\text { to work together and they didn't } \\
\text { like to share the same short story } \\
\text { or work in a group" (I1.Literature } \\
1.21 \text {, Professor). }\end{array}$ & 8 \\
\hline & $\begin{array}{ll}\text { Lack } & \text { of } \\
\text { motivation } & \text { to } \\
\text { read } & \end{array}$ & $\begin{array}{l}\text { Reasons why students are } \\
\text { discouraged from reading. }\end{array}$ & $\begin{array}{l}\text { "I want to get to know Chile and its } \\
\text { culture, but without having to read, } \\
\text { because I plan to learn more things } \\
\text { by traveling around Chile" (FG2. } \\
\text { Literature } 1.53 \text {, Student } 8.2 \text { ). }\end{array}$ & 10 \\
\hline \multicolumn{2}{|c|}{ 2. Lack of prior knowledge } & $\begin{array}{l}\text { The lack of world knowledge } \\
\text { that the difficulty of the } \\
\text { curricular content remarks }\end{array}$ & $\begin{array}{l}\text { "Before, students from Spanish } \\
\text { majors were joining these courses. } \\
\text { So, it was for people who studied } \\
\text { Spanish and literature classes and } \\
\text { today the student of these courses } \\
\text { may have studied a couple of classes } \\
\text { specialized in something else. I } \\
\text { don't know, it's very different from } \\
\text { what it was at the beginning" (I2. } \\
\text { Literature 2. 30, Professor). }\end{array}$ & 50 \\
\hline \multicolumn{2}{|c|}{$\begin{array}{l}\text { 3. Lack of experience in other exchange } \\
\text { contexts }\end{array}$} & $\begin{array}{l}\text { The learner has no experience } \\
\text { in another student mobility } \\
\text { program. }\end{array}$ & $\begin{array}{l}\text { Percentages from the student } \\
\text { survey (Graphic 5) }\end{array}$ & 54 \\
\hline
\end{tabular}

Source: Elaborated by the author of this article 
The second factor expressed the student's preference for individual work, even though the professors proposed the group work modality as an alternative to facilitate the reading task, as mentioned by a professor in the semi-structured interview:

"Look, I can't confirm this totally, but I have noticed that they prefer to work alone in general" (I1. Literature 1.21, Professor).

The third factor, on the other hand, revealed the lack of motivation of students in reading, which invites to reflect on the types of texts assigned and their degree of difficulty, as stated by a student in the focus group carried out in a Literature course:

"I understand the benefits of reading, but no, if I have free time on the beach, I'm going to put the music on and will not read. The texts are too complex, and they don't encourage me to read without a score" (FG1. Literature 2.50, Student 3).

The second sub-theme was related to the lack of prior knowledge, in particular the one associated with reading content. As one of the professors clarified in the semi-structured interview, this was attributed to the student's interest in learning the language, without necessarily specializing in a certain discipline:

"I would say that half of the students have prior knowledge and half don't, because many are in these courses only to learn the language. Not necessarily, because they are interested in social sciences or history" (I2. History 2.7, Professor).

According to what the students stated in the focus groups, they chose the courses because of the convenience of the schedule or the recommendation of former students and/or academic coordinators. Possibly, therefore one of the History professors linked this lack of knowledge to the students' practical motivations for learning the language:

"If I were to go to China I would join a course to learn about Chinese painting, even though I know nothing. I would still enroll in that course, but without putting any effort into it, and that's why I understand the logic of the exchange student" (I2. History 2.17, Professor).

The complexity of the texts awakened in professors and students the need to generate strategies to connect with other types of prior knowledge. Through the analysis, the strategies used by the students to relate the information in the text to their previous experience were identified, among them, the following ones stood out:

1. Evoking their world knowledge and all their personal experiences that are related to the text (personal):

"I find it easy because I went to Isla Negra and I know a little about Pablo Neruda" (P7. Literature 2. Student9).

2. Associate the text with the international students' culture

(personal):

"I think this church has the same spirit as the one I have in my country. People greet: Hello, how are you? (P2. History 2.15, Presenter)

3. Compares linguistic aspects of the learners' mother tongue with the target language (idiomatic):

"The Creoles called it football to the football game and the name Wonders is a word that in English means vagabond" (P3. History 1.17 , Presenter).

4. Link the text with a specific activity carried out in the previous class (contextual):

"And now, I am going to present about Saint Paul's Church in Valparaiso that we visited last week on the field trip" (P2. History 1.17 , Presenter).

5. Connect the text with information raised in the previous class (contextual):

"It is a bit similar to the story of the tree that we saw in another previous class. They are similar in focusing on women's rights, but I think it is one of the earliest feminist stories" (P2. Literature 1, Student1).

6. Situate the text in context and link it to other previous readings (contextual):

"In 1857 it was built, although only Catholic churches were allowed during this time in the country as we have read in our readings for this class" (P2. History 2.17, Professor).

7. Contrast the text with other similar works (contextual):

"We saw this concept last class in a text called the transformations in the forms of struggle" (P4. History 1.2, Professor).

By classifying these strategies according to the prior knowledge that the participants activate, it has been concluded that the first two strategies represent the learner's world knowledge. Category three works on the similarities between the two languages by establishing a comparison that enhances language knowledge. Finally, categories 4, 5, 6, and 7 aim to build knowledge based on the context of previous activities or readings. Moreover, the timing of the use of these strategies during the lesson is of great relevance, as professors and presenters established this link with prior knowledge as a closure to the session. However, it is suggested to use them at the beginning of the session, as it can help to compensate for the lack of contextualization of the texts. Another practical alternative is to contextualize the reading in a session prior to the presentation to improve interaction with the text. 
The third sub-theme attributed the students' lack of world knowledge to another cause, which centered on a lack of experience in another student exchange program. This lack had an impact on understanding the texts assigned in the reading task. This, together with the lack of prior knowledge, were probably the most recurrent reasons in this theme as they, according to the students, affected their comprehension of the texts. The students' responses in the student survey pointed to the fact that most of them had no experience in a different exchange program before coming to Chile, as shown in Graphic 5.

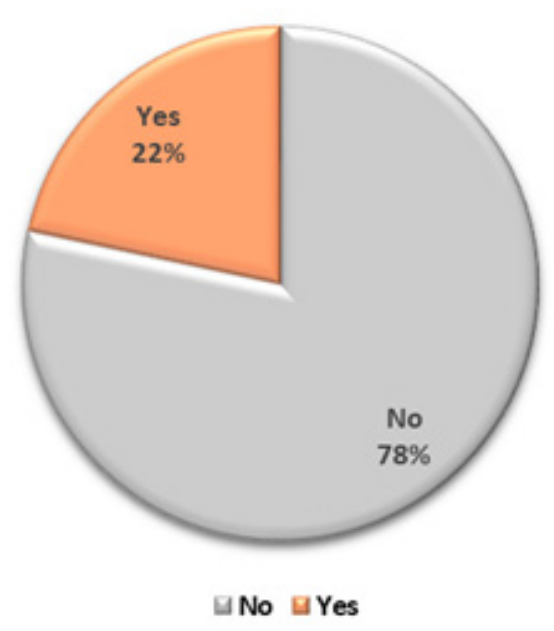

\section{Graphic 5. Students' experience in another student exchange program}

Facing a text difficulty during the exchange revealed a divergence between the curricula of the home country and the one in Chile. This difference between curricula invites debate on the need to standardize the criteria and requirements of Spanish L2 Teaching Programs. As mentioned previously those differences cause a lack of motivation and make students shyer and unwilling to participate in class and this itself is an indicator that curricular difficulty plays against enjoying learning this foreign or second language.

This investigation had an objective to explore the relation between curricular material, topic familiarity, and topic interest in Spanish a second language teaching context. The findings of the various data collection instruments made it possible to attain this objective by offering a more detailed and critical look at the case at hand through the discussion of the results of the instruments in interaction.

The discussion of the statements of both students and professors allowed us to determine the characteristics of the curriculum and the reason why it did not fit with the students' topic interests and reflected the lack of topic familiarity that they had. The results of the focus group and the semi-structured interview led to classifying these statements in order to achieve a detailed characterization of the curriculum and the aspects that made it difficult for learners.

Generally speaking, the technical or subject-specific vocabulary in the authentic texts did not allow learners to reuse it in everyday conversations that would satisfy the purposes they considered practical. Professors in this Spanish literacy setting should have been more strategic in their choice of teaching materials, in deciding when to teach with authentic texts and how much of them had to be part of the second language curriculum. No matter how advanced the learner's level, he or she might feel that he or she lacks sufficient linguistic knowledge to cope with them. The cultural aspects addressed by the texts were far from the topics with which the students were familiar (ZYZIK and POLIO, 2017). These findings are consistent with the results of the present study, given that the advanced level of language proficiency did not exempt the students from the difficulties of authentic texts.

This implies that the curriculum design should have been consistent with the authenticity of the text and the difficulty involved (AKBARI and RAZAVI, 2016). Given this complexity, it is advisable to assign tasks with specific parts of the text such as searching for certain information and answering direct or inferential questions, as revising the whole text can become a highly demanding and exhausting goal for the vast majority of learners.

At the same time, the focus of the texts on the Latin American socio-cultural context did not allow students to connect with previous experience, as they did not have similar world knowledge related to this domain-specific literacy. For this reason, they evoked knowledge of similar personal experiences or language knowledge in order 
to facilitate the content and to be prepared for oral presentation. Hence, this study supports a difference between the content of the texts and the students' prior experience. This difference could be attributed to the lack of world knowledge associated with the curricular area and the context of student exchange in which the reading takes place.

In addition, the texts were selected without thinking about how appropriate they were for the student's level of proficiency or interests. According to Solé (1992) reading begins to motivate the learner when it connects with his or her personal interests. As an example, a student learning Spanish to get a job opportunity will not need to read specialized texts in arts but will be interested in reading for a specific purpose to learn more about situational contexts at the workplace.

These findings corroborate the theoretical assumptions of Stoller (2004) and Akbari and Razavi (2016) who argue that the content taught in the classroom should be consistent with the students' learning objectives. In this sense, the analysis of the data of the present study showed that the reading during the exchange was focused on disciplinary areas that were probably unfamiliar to the students and, for this very reason, they should be directly involved in the selection of texts to ensure their engagement with the subject matter (MCKENNA and ROBINSON, 2006). Similarly, Stoller (2015) suggests that when students are involved in the selection of texts, they enjoy reading more and feel more committed to the task, which invites reflection on the relevance of the involvement of the learner in the process of selecting course material during the exchange. When they are part of the process, they are more motivated and learn better, because they reflect on the content of the texts while choosing them.

\section{CONCLUSIONS AND IMPLICATIONS}

Our results support the argument that students should be part of the text selection process by suggesting readings or topics that they would like to learn about. It is also proposed that professors should make a balance between authentic texts and adapted ones for the students' level, in order to ensure that the reading task is challenging, but at the same time achievable. It is also recommended to use graded or shorter versions of the original texts. Additionally, we suggest sending students a quick survey before starting the L2 courses to know more about their abilities and goals, this could help to design engaging instructional material. Finally, future work is needed in other Spanish teaching settings inside and outside Chile to contrast those findings and compare them in other disciplinespecific settings.

On the other hand, Spanish L2 programs should start to establish certain criteria and specifications to unify teaching materials. As probably differences do not only lie in the design of these programs, but also in the linguistic variation of the Spanish they teach and the learning books they use. Therefore, efforts should be made to standardize L2 curriculums at the international level, which is not a minor challenge, since curriculum alliances have not yet been established at the national or regional levels. Which means that a lot of further efforts are needed to get there especially that $\mathrm{L} 2$ teaching should be a common responsibility between the country of origin where student learn the language for the first time and the one that hosts the mobility program and will be building upon students L2 knowledge.

\section{REFERENCES}

AKBARI, O.; RAZAVI, A. (2016). Using authentic materials in the foreign language classrooms: Teachers' perspectives in EFL classes. International Journal of Researcb Studies in Education, v. 5, n. 2, p. 105-116.

AKBULUT, F. D. (2020). Improving Turkish EFL Learners' Lexical Knowledge through Topic Interest-Based Reading. Dil Ĕgitimi ve Araştırmaları Dergisi, v. 6, n. 1, p. 72-87.

ALTALIB, A. (2019). L2 Motivation in ESP and EGP Courses: An Investigation of L2 Motivational Selves among Learners of English in Saudi Arabia. Australian Journal of Applied Linguistics, v. 2, n. 1, p. 1-16.

ANDRIJEVIĆ, M. (2010). Reflexiones en torno al uso de los materiales auténticos en la enseñanza de lenguas extranjeras. Colindancias-Revista de la Red de Hispanistas de Europa Central, n. 1, p. 157-163. 
BRÅTEN, I.; MCCRUDDEN, M. T.; STANG LUND, E.; BRANTE, E. W.; STRØMS $\varnothing$, H. I. (2018). Task-oriented learning with multiple documents: Effects of topic familiarity, author expertise, and content relevance on document selection, processing, and use. Reading Research Quarterly, 53(3), 345-365.

CRESWELL, J. (2013). Qualitative inquiry and research design: Choosing among five approaches. Thousand Oaks: Sage

ERÇETIN, G. (2010). Effects of topic interest and prior knowledge on text recall and annotation use in reading a hypermedia text in the L2. ReCALL: the Journal of EUROCALL, v. 22, n. 2, p. 228.

GARCÍA, M. D. (2007). Cómo llevar la literatura al aula de ELE: de la teoría a la práctica. marcoELE. Revista de Didáctica Español Lengua Extranjera, n. 5, p. 1-51.

GILMORE, A. (2011). "I prefer not text": Developing Japanese learners' communicative competence with authentic materials. Language learning, v. 61, n. 3, p. 786-819.

GIRONZETTI, E.; LACORTE, M.; MEREDIZ, E.; BARTIS, S. (2020). Evaluación y rediseño curricular para la integración de lengua, cultura y literatura en programas de español como L2. Revista Nebrija de Lingüística Aplicada a la Enseñanza de Lenguas, v. 14, n. 28, p. 12-35.

GUO, S. (2012). Using authentic materials for extensive reading to promote English proficiency. English Language Teaching, v. 5, n. 8, p. $196-206$.

HANSEJORDET, I. (2012). La marginación de la literatura y de Hispanoamérica en el español como lengua extranjera. Nordic Journal of Modern Language Methodology, v. 1, n. 1, p. 1-15.

MAHMOUDI, S.; MAHMOUDI, A. (2017). Can topic familiarity override language proficiency in reading comprehension? Journal of Language Teaching and Research, v. 8, n. 3, p. 496-506.

MARTÍNEZ, A. (2009). Empirical study of the effects of discourse markers on the reading comprehension of Spanish students of English as a foreign language. International Journal of English Studies, v. 9, n. 2, p. 19-43

MCKENNA, M. C.; ROBINSON, R. D. (2006). Teaching through text: Reading and writing in the content areas. Boston: Pearson/Allyn \& Bacon

MCNAMARA, D.; KINTSCH, W. (1996). Learning from texts: Effects of prior knowledge and text coherence. Discourse processes, v. 22, n. 3 , p. $247-288$

MENKE, M. R.; PAESANI, K. (2019). Analysing foreign language instructional materials through the lens of the multiliteracies framework. Language, Culture and Curriculum, v. 32, n. 1, p. 34-49.

MERRIAM, S.; GRENIER, R. (2019). Qualitative Research in Practice: Examples for Discussion and Analysis. New Jersey: John Wiley \& Sons.

MORENO, N.; MALOVRH, P. A. (2020). Restructuring a beginner language program: a quantitative analysis of face-to-face versus flipped-blended Spanish instruction. Hispania, v. 103, n. 2, p. 259-274.

MORTON, T. (2019). Teacher education in content-based language education. In WALSH, S.; MANN, S. (Eds.). The Routledge Handbook of English Language Teacher Education. London and New York: Routledge, p. 169-83.

PAESANI, K. (2017). Redesigning an introductory language curriculum: A backward design approach. L2 Journal, v. 9 , n. 1.

PULIDO, D. (2004). The relationship between text comprehension and second language incidental vocabulary acquisition: A matter of topic familiarity? Language learning, v. 54, n. 3, p. 469-523.

PULIDO, D. (2007). The effects of topic familiarity and passage sight vocabulary on L2 lexical inferencing and retention through reading. Applied linguistics, v. 28, n. 1, p. 66-86. 
QIU, X., \& LO, Y. Y. (2017). Content familiarity, task repetition and Chinese EFL learners' engagement in second language use. Language Teaching Research, v. 21, n. 6, p. 681-698.

QSR International. (2018). NVivo 12 pro. London: QSR International Pty Ltd.

SALAS, J. (2013). Necesidad de textos autenticos y adaptados en la ensenanza del idioma ingles con fines especificos. Pedagogía universitaria, v. 18, n. 4, p. 91-104.

SCHIEFELE, U. (1999). Interest and learning from text. Scientific studies of reading, v. 3, n. 3, p. 257-279.

Sequero, M. (2015). La literatura como recurso didáctico en la enseñanza del español como lengua extranjera. Tejuelo, n. 21, p. $30-53$.

SHAKOURZADEH, L., \& IZADPANAH, S. (2020). Textbook-assigned and self-selected topics of Iranian male EFL learners: topic interest, topic familiarity, topic importance, and topic difficulty. Asian-Pacific Journal of Second and Foreign Language Education, v. 5, n. 1, p. 1-23.

SOEMER, A., \& SCHIEFELE, U. (2019). Text difficulty, topic interest, and mind wandering during reading. Learning and Instruction, v. 61, p. 12-22.

SOLÉ, I. (1992). Estrategias de lectura. Barcelona: Grao.

STOLLER, F. L. (2004). 12. Content-Based instruction: perspectives on curriculum planning. Annual review of applied linguistics, v. 24, p. 261-283.

STOLLER, F. L. (2015). Viewing extensive reading from different vantage points. Reading in a Foreign Language, v. 27, n. 1, p. $152-159$.

ZYZIK, E. C.; POLIO, C. (2017). Authentic materials myths: Applying second language research to classroom teaching. Michigan, MI: University of Michigan Press. 


\section{APENDIX A: SURVEY}

Regarding your language ability in Spanish classes at your home country how would you rate the following aspects considering 1 as the lowest ability and 7 the highest ability

1. Your ability to understand readings assigned at classes.

2. Your ability to discuss those readings in class.

3. Your ability to elaborate on opinions based on previous readings.

4. Your ability to integrate your insights based on previous readings.

5. Your ability to interact in Spanish on familiar topics.

From 1 (lowest) to 7 (highest), how would you rate your previous language classes with regards to:

1. The difficulty of the reading assignments you had before coming to Chile.

2. The amount of reading issues you had during your Spanish language development.

3. The amount of help and intervention of the lecturer during the readings assigned in language classes.

4. The opportunities for you to share your previous personal experiences at class.

5. The opportunities to clarify doubts regarding the texts.

Please answer the following questions and tell us more about your experience and opinions in this regard:

1. What courses did you take in Spanish before coming to Chile? Please specify at which university or institute and name any Spanish courses you have done before.

2. What are the similarities and differences between your experience with the readings in class in Chile and in your home country?

3. What did you like about your reading classes?

4. What would you do to improve the reading experience in class in both cases?

\section{APPENDIX B: SEMI-STRUCTURED INTERVIEW}

1. How would you describe the performance of the students in this course compared to previous years?

2. How long have you been using the texts listed in the Program?

3. How often do you assign readings in class?

4. What is the dynamic of discussing the readings in class?

5. What is the importance of reading for you?

6. What are the main themes and characteristics of these texts?

7. When you ask your students to read, what exactly do you ask them to do.

8. Why do you prefer using these texts?

\section{APPENDIX C: FOCUS GROUP}

1) What Spanish texts did you use to read mostly before coming to Chile and why?

2) Generally speaking, why do you read in Spanish?

3) How many of you have not studied Historia/Literature before? Why did you decide to join this course although it's not your major/minor?

4) Why do you think readings assigned in Chilean courses are different from the one you used to read in your country?

Recebido: 2/3/2021

Aceito: 8/5/2021

Publicado: 17/5/2021 